\title{
Antibacterial Effect of Vernonia Amygdalina and Ocimum Gratissimum on Some Bacteria that Cause Opportunistic Infections in HIV/AIDS Patients
}

\author{
Kolawole Sunday $^{1^{*}}$, Obueh Henrietta ${ }^{2}$ and Ukachi Augusta ${ }^{3}$ \\ ${ }^{1,3}$ National Open University of Nigeria, Benin City Study Centre, Benin City Nigeria \\ ${ }^{2}$ Biology Department, College of Education, P.M.B 1144, Ekiadolor, Benin City
}

Received: January 08, 2018; Accepted: February 16, 2018; Published: February 26, 2018

*Corresponding author: Kolawole Sunday, National Open University of Nigeria, Benin City Study Centre, Benin City Nigeria, E-mail: kolasunde@ gmail.com

\begin{abstract}
Antibacterial effect of Vernonia amygdalina (Bitter leaf) and Ocimum gratissimum (Scent leaf) on Escherichia coli, Staphylococcus aureus and Pseudomonas aeruginosa that cause opportunistic infections in HIV/AIDS patients was studied. The extract of Ocimum gratissimum had higher antibacterial effect, though not significant $(P>0.05)$, on the bacterial isolates than the extract of Vernonia amygdalina. The Ocimum gratissimum extract had higher quantity of phytonutrients (alkaloid, steroid, tannin and flavonoid) than the extract of Vernonia amygdalina. Susceptibility of the bacterial isolates was in the order Escherichia coli > Pseudomonas aeruginosa $>$ Staphylococcus aureus to the Ocimum gratissimum and Vernonia amygdalina extracts at concentrations $30 \mathrm{mg} / \mathrm{ml}$ to $150 \mathrm{mg} / \mathrm{ml}$. At concentration of $30 \mathrm{mg} /$ $\mathrm{ml}$, the Vernonia amygdalina extract was not inhibitory to $S$. aureus and P. aeruginosa. However, the extract of Ocimum gratissimum inhibited all the test organisms with higher diameter of the zones of inhibition. The use of Ocimum gratissimum extract could help reduce the effect and complications of opportunistic infections caused by $E$. coli, S. aureus and P. aeruginosa in HIV/AIDS patients.
\end{abstract}

Keywords: Antibacterial, Vernonia amygdalina, Ocimum gratissimum, opportunistic infections, HIV/AIDS patients.

\section{Introduction}

The Human Immunodeficiency Virus (HIV) results in life threatening opportunistic infections and malignancies [14]. It destroys the body's ability to fight against infections, and reduces the functional impairment and damages the immune system. Opportunistic infections are caused by pathogen such as bacteria, viruses, fungi and protozoans. The CD4 lymphocyte count plays a major role in HIV/AIDS patients [22]. Most opportunistic infections occur when the CD4 lymphocyte count is below 200cells/mm3 and this CD4 cell decrease has been traced to the activity of oxidative cells, thereby affecting the immune system and patients' recovery rate on antiretroviral therapy [23]. Some of the opportunistic infections include tuberculosis, pneumonia, diarrrhoea, malaria, candidiasis, cancers, cardiovascular disease, osteoporosis, lung or kidney disease (WHO, 2013). Hence, the exogenous supply of antioxidants, as natural compounds that scavenge free radicals might represent an important additional strategy for the treatment of HIV infection [30].

Phytomedicines derived from plants have shown great promise in the treatment of intractable infectious diseases including opportunistic infections in people living with HIV/ AIDS [4]. Phytochemicals are biologically active, naturally occurring chemical compounds found in plants, which provide health benefits for humans further than those attributed to macronutrients and micronutrients [15]. Plants contain a wide variety of free radical scavenging molecules such as flavonoids, anthocyanins, cartenoids, dietary glutathionine, alkaloids, tannins, saponins, steroids, terpenoids and rotenoids which are rich in antioxidants activities [31]. Many of these plant- derived substances show anti-HIV activity e.g. alkaloids, flavonoids, coumarins, tannins, catechin, steroids and terpenoids [23]. Vernonia amygdalina (bitter leaf) is a small shrub that grows predominantly in tropical Africa. It is called bitter leaf because of its bitter taste. The bitterness is as a result of the presence of the sesquiterpenes lactones and steroid glycosides [13]. The leaf also contains some phytochemical compounds such as alkaloid, flavonoids, glycosides, saponin, tannin, steroids, proteins and carbohydrates in high concentration [38]. The aqueous extraction of bitter leaf could be used as adjuvant in the management of people living with HIV/AIDS as well as boosting immunity and a panacea for skin blemishes [7]. Ocimum gratissimum (scent leaf) is commonly used in cooking due to its minty and aromatic flavor. It is rich in alkaloids, tannins, flavonoids, phytates, resins, glucosides oligosaccharides and essential oils such as eligenol and thymol, which are responsible for its antibacterial, anti- diabetic and anti-malaria properties [27]. Study by Ayisi and Nyadedzor (2003) showed that extracts of scent leaf had inhibited HIV-I strain HTLVIII (B) cytopathicity and had high antiviral indices. Scent leaf has been described to be active against several species of bacteria and fungi and has proved useful in the medication for people living with HIV/AIDS [26, 11]. Therefore, this study is to investigate the antibacterial effect of the extracts of Vernonia 
amygdalina and Ocimum gratissimum on clinical isolates of E. coli, S. aureus and P. aeruginosa.

\section{Materials and Methods}

\section{Sample Collection and Preparation of Extracts}

Fresh leaves of Vernonia amygdalina (bitter leaf) and Ocimum gratissimum (scent leaf) were collected from Koko village (Latitude $6^{\circ} 04 \mathrm{~N}$ and Longitude $5^{\circ} 283 \mathrm{E}$ ) in Warri North Local Government Area of Delta State, Nigeria. The plants were identified and authenticated. The fresh leaves were washed with distilled water, sun dried for fifteen days and then milled into powder using an electrical grinder. Thirty grams (30 g) of the ground bitter leaf were placed in $100 \mathrm{ml}$ of deionised water in a $500 \mathrm{ml}$ beaker and stirred vigorously. This was then filtered using Whatmann No1 filter paper. The filtrate was evaporated to dryness using a rotatory evaporator [2]. The same procedure was carried out for the scent leaf. The extracts were scored at $4^{\circ} \mathrm{C}$, until analyses were done.

\section{Preparation of Test Organisms}

The pure clinical isolates of the experimental bacterial strains of E. coli, S. aureus and P. aeruginosa were obtained from the department of medical microbiology and parasitology, Central Hospital, Benin City. They were isolated and purified on Nutrient Agar slants and identified using their cultural, morphological and biochemical characteristics. The agar slants were preserved in the incubator at $37^{\circ} \mathrm{C}$.

\section{Phytochemical Analyses}

Phytochemical analyses were conducted on the plant extracts to determine the presence of alkaloid, glycosides, flavonoids, tannins, terpenoid, steroids, and reducing sugar. Glycoside content was determined by the method of tannin content was determined by the spectrophotometric method of alkaloid content was determined by the method of reducing sugar content was determined by the method of flavonoid content was determined by the method of terpenoid and steroid were determined by the method of $[16,3,29,19,33,18]$.

\section{Determination of Antibacterial Activity}

\section{Serial Dilution of Extracts}

Preparations of fivefold serial dilution from the extracts were carried out. One millimeter $(1 \mathrm{ml})$ of each prepared extract was added to $9 \mathrm{ml}$ of sterile distilled water in a test tube to make a $10^{-1}$ dilution $(150 \mathrm{mg} / \mathrm{ml}$ concentration $)$. This was then serially diluted to get $10^{-2}(120 \mathrm{mg} / \mathrm{ml}), 10^{-3}(90 \mathrm{mg} / \mathrm{ml}), 10^{-4}(60 \mathrm{mg} / \mathrm{ml})$ and $10^{-5}(30 \mathrm{mg} / \mathrm{ml})$ concentrations.

\section{Preparation of Disks}

Filter papers were perforated into $6 \mathrm{~mm}$ sizes. They were sterilized in an autoclaved at $121^{\circ} \mathrm{C}$ for $15 \mathrm{~min}$. A known volume of $0.1 \mathrm{ml}$ of each leaf extract was placed on different disks from the $30 \mathrm{mg} / \mathrm{ml}$ to $150 \mathrm{mg} / \mathrm{ml}$ concentrations of the serial dilution. They were allowed to dry in an incubator for $37^{\circ} \mathrm{C}$.

\section{Microbiological Assay}

Pure isolates of E. coli, S. aureus and P. aeruginosa were streaked into different prepared nutrient agar plates in triplicates and labeled. Some of the plates were incubated at $37^{\circ} \mathrm{C}$ for $24 \mathrm{~h}$ to determine microbial count. The disks containing the extracts of Vernonia amygdalina and Ocimum gratissimum were placed aseptically into the Nutrient Agar plates containing the pure isolates. They were incubated at $37^{\circ} \mathrm{C}$ for $24 \mathrm{~h}$ until marked decline in the potency of the extracts to inhibit the growth of the test organisms were noticed [26]. Zones of inhibition and the diameter of such zones were measured in millimeter. The Minimum Inhibitory Concentration (MIC) was taken as the lowest concentration of the extracts that prevented growth of the isolates after comparing the different concentration of the extracts from the zones of inhibition [1].

\section{Statistical Analysis}

Data obtained were analyzed using a two way analysis of variance (ANOVA) and values for $\mathrm{P}<0.05$ were considered statistically significant.

\section{Results}

The result of the phytochemical analysis is presented in table 1. The presence of all the phytochemical content tested was observed in the extracts of Vernonia amygdalina and Ocimum gratissimum which is the basis of the therapeutic potentials of the extracts. The extract of Ocimum gratissimum had higher presence of alkaloid, steroid, flavoid and tannin than the extract of Vernonia amygdalina by colour indication. The bacterial count $(\mathrm{cfu} / \mathrm{ml})$ of the isolates in the Nutrient Agar containing the extracts is presented in table 2 . The bacterial counts of the isolates ranged from $0.8 \pm 0.01$ to $1.5 \pm 0.08 \mathrm{cfu} / \mathrm{ml}, 1.3 \pm 0.05$ to $1.9 \pm 0.01 \mathrm{cfu} /$ $\mathrm{ml}$ and $1.2 \pm 0.05$ to $1.6 \pm 0.04 \mathrm{cfu} / \mathrm{ml}$ in the extract of Vernonia amygdalina and the bacterial counts of the isolates ranged from $0.6 \pm 0.03$ to $1.2 \pm 0.01 \mathrm{cfu} / \mathrm{ml}, 1.0 \pm 0.04$ to $1.7 \pm 1.30 \mathrm{cfu} / \mathrm{ml}$ and $0.8 \pm 0.01$ to $1.5 \pm 1.00 \mathrm{cfu} / \mathrm{ml}$ in the extract of Ocimum gratissimum. The aqueous extracts had higher antibacterial activity against the gram negative E.coli and P. aeruginosa than the gram positive $S$. aureus.

$S$. aureus was the least susceptible organism to the leaf extracts while E. coli was the most susceptible organism. The bacterial isolates were more susceptible to the extract of Ocimum gratissimum than the extract of Vernonia amygdalina. The result of the antibacterial activity of the extracts against the test organisms is show in table 3.

The mean zone of inhibition of the leaf extracts determines the antibacterial activity of the extracts. The highest antibacterial activity was shown by the leaf extracts at $150 \mathrm{mg} / \mathrm{ml}$ concentration against all the test organisms. The scent leaf extract exhibited higher antibacterial activity on the test organisms. The zone of inhibition in $\mathrm{mm}$ decreased as the dilution factor increased. The MIC was $30 \mathrm{mg} / \mathrm{ml}$ for the scent leaf (Ocimum gratissimum) extract and $60 \mathrm{mg} / \mathrm{ml}$ the bitter leaf (Vernonia amygdalina) 
Antibacterial Effect of Vernonia Amygdalina and Ocimum Gratissimum on Some Bacteria that Cause Opportunistic Infections in HIV/AIDS Patients

extract. The bitter leaf extract did not show antibacterial activity

table 4.

against $S$. aureus and P. aeruginosa at $30 \mathrm{mg} / \mathrm{ml}$ concentration in

\begin{tabular}{|c|c|c|c|c|c|c|c|}
\hline Extract & Alkaloid & Glycosides & Terpenoid & Steroid & Flavonoid & Tannin & Reducing sugar \\
\hline Scent leaf & ++ & + & + & ++ & ++ & ++ & + \\
\hline Bitter leaf & + & ++ & + & + & + & + & ++ \\
\hline $\begin{array}{c}\text { Colour } \\
\text { indication }\end{array}$ & yellow & red & reddish violet & bluish green & red & deep blue & brick red \\
\hline
\end{tabular}

Table 2: Bacterial counts (cfu/ml) of isolates in extracts of Vernonia amygdalina and Ocimum gratissimum

\begin{tabular}{|c|c|c|c|c|c|c|}
\hline & \multicolumn{9}{|c|}{ Bacterial Count (cfu/ml) x 102 } \\
\hline Concentration of extract $\mathbf{( m g / m l )}$ & $\begin{array}{c}\text { Bitter leaf } \\
\text { extract }\end{array}$ & $\begin{array}{c}\text { Scent leaf } \\
\text { extract }\end{array}$ & $\begin{array}{c}\text { Bitter leaf } \\
\text { extract }\end{array}$ & $\begin{array}{c}\text { Scent leaf } \\
\text { extract }\end{array}$ & \multicolumn{3}{|c|}{$\begin{array}{c}\text { Bitter leaf } \\
\text { extract }\end{array}$} & $\begin{array}{c}\text { Scent leaf } \\
\text { extract }\end{array}$ \\
\hline 150 & $0.8 \pm 0.01$ & $0.6 \pm 0.03$ & $1.3 \pm 0.05$ & $1.0 \pm 0.04$ & $1.2 \pm 0.05$ & $0.8 \pm 0.01$ \\
\hline 120 & $1.0 \pm 0.32$ & $0.8 \pm 0.01$ & $1.8 \pm 0.09$ & $1.3 \pm 0.08$ & $1.5 \pm 0.50$ & $0.9 \pm 0.02$ \\
\hline 90 & $1.0 \pm 0.50$ & $1.0 \pm 0.30$ & $1.7 \pm 0.35$ & $1.3 \pm 0.04$ & $1.4 \pm 0.07$ & $1.0 \pm 0.05$ \\
\hline 60 & $1.1 \pm 0.10$ & $1.1 \pm 0.06$ & $1.7 \pm 1.07$ & $1.5 \pm 0.08$ & $1.6 \pm 0.04$ & $1.3 \pm 0.08$ \\
\hline 30 & $1.5 \pm 0.08$ & $1.2 \pm 0.01$ & $1.9 \pm 0.01$ & $1.7 \pm 1.30$ & $1.6 \pm 0.08$ & $1.5 \pm 1.00$ \\
\hline
\end{tabular}

Table 3: Antibacterial activity of the extracts of Vernonia amygdalina and Ocimum gratissimum against the test organisms

\begin{tabular}{|c|c|c|c|c|c|c|}
\hline & \multicolumn{9}{|c|}{ Mean zones of inhibition (mm) } \\
\hline $\begin{array}{c}\text { Concentration of extract } \\
(\mathbf{m g} / \mathbf{m l})\end{array}$ & $\begin{array}{c}\text { Bitter leaf } \\
\text { extract }\end{array}$ & $\begin{array}{c}\text { Scent leaf } \\
\text { extract }\end{array}$ & $\begin{array}{c}\text { S. aureus } \\
\text { Bitter leaf } \\
\text { extract }\end{array}$ & $\begin{array}{c}\text { Scent leaf } \\
\text { extract }\end{array}$ & $\begin{array}{c}\text { Bitter leaf } \\
\text { extract }\end{array}$ & $\begin{array}{c}\text { Scent leaf } \\
\text { extract }\end{array}$ \\
\hline 150 & $7.0 \pm 0.03$ & $14.0 \pm 0.10$ & $3.0 \pm 0.05$ & $9.0 \pm 0.05$ & $4.0 \pm 0.08$ & $10.0 \pm 0.50$ \\
\hline 120 & $6.0 \pm 0.10$ & $12.0 \pm 0.05$ & $3.0 \pm 0.01$ & $7.0 \pm 0.10$ & $7.0 \pm 0.17$ & $9.0 \pm 0.10$ \\
\hline 90 & $4.0 \pm 0.05$ & $10.0 \pm 0.08$ & $2.0 \pm 0.05$ & $5.0 \pm 0.07$ & $3.0 \pm 0.03$ & $8.0 \pm 0.05$ \\
\hline 60 & $2.0 \pm 0.01$ & $7.0 \pm 0.10$ & $2.0 \pm 0.0$ & $5.0 \pm 0.01$ & $3.0 \pm 0.01$ & $6.0 \pm 0.08$ \\
\hline 30 & $1.0 \pm 0.01$ & $5.0 \pm 0.01$ & - & $2.0 \pm 0.05$ & & $4.0 \pm 0.01$ \\
\hline Note: - = No zone of inhibition & & & & & & \\
\hline
\end{tabular}

Table 4: Minimum inhibitory concentration (MIC) of the extracts of Vernonia amygdalina and Ocimum gratissimum

\begin{tabular}{|c|c|c|}
\hline \multicolumn{2}{|c|}{ MIC $(\mathrm{mg} / \mathrm{ml})$} & Scent leaf extract \\
\hline Test organisms & Bitter leaf extract & 30 \\
\hline E. coli & 30 & 30 \\
\hline S. aureus & 60 & 30 \\
\hline P. aeruginosa & 60 & 30 \\
\hline
\end{tabular}




\section{Antibacterial Effect of Vernonia Amygdalina and Ocimum Gratissimum on Some Bacteria that Cause Opportunistic Infections in HIV/AIDS Patients}

\section{Discussion}

The higher presence of steroids, flavonoids, alkaloids and tannins in Ocimum gratissimum (scent leaf) than in Vernonia amygdalina (bitter leaf) could have attributed to its higher antibacterial activity against the test organisms. This agreed with report of [25]. The presence of these antibacterial components may have invariably led to the degree of antibacterial activity on the test organisms. An important characteristic of the plant extracts and their components is their hydrophobicity, which enabled them to partition the lipids of the bacterial cell membranes and mitochondria, disturbing the cell structures and rendering them more permeable [36]. The inhibition produced by the plant extracts against particular organism depends upon various extrinsic and intrinsic parameters [17]. S. aureus was the least susceptible organism while E. coli was the most susceptible organism with the action of the leaf extracts. This is in disagreement with the report of where ethanol extracts of o. gratissimum showed more antibacterial activity against $S$. aureus than E. coli [26]. The result of this study is in agreement with the study of that showed that E. coli was more sensitive to the deleterious effect of the extract of 0 . gratissimum than $S$. aureus due to presence of different phytochemicals contained in the plant [2]. Flavonoids which are also known as vitamin $p$ or plan modifier elicits a wide range of therapeutic activities as antihypertensive, antirheumatic as well as antimicrobial [39]. Plants containing flavonoids have diuretic and antioxidant properties [12]. Glycosides have been used for over two centuries as stimulant in cases of cardiac failure and disease [37]. Alkaloids have many pharmacological activities including antihypertensive effects, antiarrhythmic effect, antimalarial activity and anticancer actions [34]. Some alkaloids are useful against HIV infections as well as intestinal infection associated with AIDS [35]. Tannins play an important role in promoting wound healing [28]. They are a major group of compounds that act as primary antioxidants or free radical scavengers [32]. Tannin containing plant extracts are used as astringents against diarrhoea, as diuretics, against stomach and duodenal tumors and as anti-inflammatory, antiseptic, antioxidant and haemostatic pharmaceuticals [8,9]. Terpenoids have medicinal properties such as anticarcinogenic, antimalarial, antiulcer, hepaticidal, antimicrobial or diuretic activity and the sesquiterpenoid antimalarial drug artemisinin and the diterpenoid anticancer drug taxol [10]. Steroids are important compounds due to their relationship with such compounds as sex hormones [6].

The bacterial counts in $\mathrm{cfu} / \mathrm{ml}$ reduced with increased concentration of the leaf extracts for all the test organisms with E. coli having the lowest bacterial counts. This could be attributed to the effect of the leaf extracts on the carbon metabolism, respiratory activities and inhibition of dehydrogenase activities of the bacterial strains $[24,2]$. The diameter zones of inhibition reported in the study is higher compared to that reported in the study of [26]. The aqueous extract of 0 . gratissimum exhibited higher inhibitory effects at all concentrations than the aqueous extract of $V$. amygdalina due to the fact that $O$. gratissimum oils have properties that can inhibit the growth of psychrophiles and heat resistant organisms [20]. It is suggested that there is need for the use of this plant and its derivative for the primary purpose of flavouring foods and exhibiting antimicrobial activities. Also, the result established a good support to the use of this plant in herbal medicine and as base for the development of new drugs in phyto-medicine especially in the prevention and treatment of opportunistic infections in HIV/AIDS patients [20,4].

\section{Conclusion}

The plant extracts, especially Ocimum gratissimum, are sources of important chemical compounds that could inhibit the growth of the test organisms that cause some opportunistic infections in people living with HIV/AIDS. It is therefore necessary to isolate these active compounds and possibly develop then into drugs to manage HIV/AIDS.

\section{References}

1. Agatemor C. Antimicrobial Activity of aqueous and ethanol extracts of nine Nigerian species against four food borne bacteria. Electronic Journal of Environment, Agriculture and Food Chemistry. 2009;8(3):195-200

2. Akujobi CO, Ogbulie, JN and Njoku HO. The extract of Ocimum gratissimum on the dehydrogenase activities to clinical isolates of Escherichia coli and Staphylococcus aureus. Journal of Agricultural Technology. 2010;6(1):57-65.

3. AOAC. Association of Official Analytical Chemist. Official Methods of Analysis 18th edition Washington DC USA.

4. Atata RF, Sani A, Ajewole SM. Effect of stem bark extracts of Enantia chloranta on some clinical isolates. Nigerian Society for Experimental Biology. 2003;15(2):84-92.

5. Ayisi NK and Ngadedzor C. Comparative in vitro effects of AZT and extracts of Ocimum gratissimum, Ficus polita, Clausena anisata, Alchornea cordifolia and Elaeophorbia drupifera against HIV-1 and HIV-2 infections. Antiviral Res. 2003;58(1):25-33.

6. Bell E. Vitamin D3 promotes immune function on the skin.

7. Chukwuma M. How bitter leaf boosts immunity with HIV, heals skin blemishes? The Guardian Newspapers 27th June 2013.

8. De Bruyne T, Pieters L, Deelstra H and Vlietinck A. Condensed vegetables tannins: biodiversity in structure and biological activities. Biochemical System Ecology. 1999;27(4):445-459.

9. Dolara P, Luceri C, De Filippo C, Femia AP, Giovannelli C, Carderni G, et al. Red wine polyphenols influence carcinogens, intestinal microflora, oxidative damage and gene expression profiles of colonic mucosa in F344 rats. Mutation Research. 2005;591(1-2):237-246.

10. Dudareva N, Pichersky E and Gershanzon J. Biochemistry of plant volatiles. Plant Physiol. 2004;135(4):1893-1902. doi: 10.1104/ pp.104.049981

11. Elujoba A. A Studies on the anti diarrhoea activity of Ocimum gratissimum. University of Ile-Ife press, 2000.

12. Esseiett UA, Bala DN and Agbakahi JA. pharmacognostic studies of the leaves and stem of Diodiascandens SW in Nigeria. Archives of Applied Science Research. 2010;2(5):124-128.

13. Farombi EO and Owoeye O. Antioxidative and chemopreventive 
properties of Vernonia amygdalina and Garcina biflavonoid. Int Environ Res Public Health. 2011;8(6):2533-2555. doi: 10.3390/ ijerph8062533

14.Gopinath SM, Vidya GM, Suneetha TB, Ismail Shareef M, Narasimha Murthy TP, et al. Screening of major bio-active compounds of few medicinal plants for anti- HIV properties. International Journal of Innovative Research in science, Engineering and Technology.2014;3(6):13785-13791.

15. Hasler CM and Blumberg JB. Phytochemicals: biochemistry and physiology. J Nutr. 1999;129(3):756S-757S.

16.Jaffe CS. Analytical Chemistry of Foods. Blackie Academic and Professional, New York 1:200.

17. Joshi B, Sah GP, Basnet BB, Bhatt MR, Sharma D, Subedi K, et al. Phytochemical extraction and antimicrobial properties of different medicinal plants: Ocimum santum (Tulsi), Eugenia caryophyllata (Clove), Achyranthes bidentata (Datiwan) and Azadirachta indica (Neem). Journal of Microbiology and Antimicrobials. 2011;3(1): 1-7.

18. Kantamreddi VSSN, Lakshmi YN and Kasapu VS. Preliminary phytochemical analysis of some important Indian plant species International Journal of Pharma and Bio Sciences. 2010;1(4):351-358.

19. Kimaryo VW, Massawi GA, Olasupo NA and Holzapfel WH. The use of a starter culture in the fermentation of cassava for the production of 'kivunde' a traditional Tanzanian food product. Int J Food Microbiol. 2000;56(2-3):179-190

20. Mbata $\mathrm{T}$ and Saikia A. Antibacterial activity and phytochemical screening of crude ethanolic extract of leaves of Ocimum gratissimum L. on Listeria monocytogenes. The internet Journal of Microbiology. 2007;4(2):1-13

21. Mbata TI and Saikia A. Antibacterial activity of essential oil from Ocimum gratissimum L. on Listeria monocytogenes. International Journal of Food Safety. 5(7):15-19.

22. Merson MH. The HIV - AIDS pandemic at 25 - the global response. The New England Journal of Medicine. 354:2414-2417.

23. Momoh MA, Muhamed U, Agboke AA, Akpabio EI and Uduma EO. Immunological effect of aqueous extract of Vernonia amygdalina and a known immune booster called immunace ${ }^{\circledR}$ and their admixtures on HIV/AIDS clients: a comparative study. Asian Pac J Trop Biomed. 2012;2(3):181-184. doi: 10.1016/S2221-1691(12)60038-0

24. Nwaogu LA, Alisi CS, Ibegbulem CO and Igwe CU. Phytochemical and antimicrobial activity of ethanolic extract of Landolphia avariensis leaf. African Journal of Biotechnology. 2007;6(7):890-893.

25. Nweze EI, Okafor JI and Njoku O. Antimicrobial activities of methanolic extracts of Trema guineensis (Schumm and Thorn) and Morinda lucida Benth used in Nigerian. Bio - Research. 2004;2(1):39-46.

26. Nwuiyi OC, Chiedu NS, Ajani OO, Ikpo CO, Ogunniran KO. Antibacterial effects of extracts of Ocimum gratissimum and piper guineense on Escherichia coli and Staphylococcus aureus. African Journal of Food Science. 3(3):77-81.
27. Oboh FOJ, Madsodje HI and Enabulele SA. Nutritional and antimicrobial properties of Ocimum gratissimum leaves. Journal of Biological Sciences. 2009;9(4):377-380.

28. Olajide O, Idowu D, Okolo S, Orishadipe A and Sunday T. Phytochemical and antioxidant properties of some Nigerian medicinal plants American Journal of Scientific and Industrial Research. 2013;4(3):328332.

29. Onwuka G. Food Analysis and Instrumentation. Naphobia Prints. 3rd Ed. A Division of HG Support Nigeria Ltd pp 133-161.

30. Otang WM, Grierson DS and Ndip RN. Phytochemical studies and antioxidant activity of two South African medicinal plants traditionally used for the management of opportunistic fungal infections in HIV/ AIDS patients. BMC Complement Altern Med. 2012;12:43. doi: 10.1186/1472-6882-12-43

31. Pham-Huy LA, He H and Pham-Huy C. Free radicals, antioxidants in disease and health. Int J Biomed Sci. 2008;4(2):89-96.

32. Polterait 0 . Antioxidants and free radicals scavengers of natural origin. Current Organic Chemistry. 1:415-440.

33. Satheesh KB, Suchetha KN, Vadisha SB, Sharmila KP and Mahesh PB. Preliminary phytochemical screening of various extracts of Punica granatum peel, whole fruit and seeds. Nitte University Journal Health Science. 2012;2(4):34-38.

34. Saxena M, Saxena J, Nema R, Singh D and Gupta A. Phytochemistry of medicinal plants. Journal of Pharmacognosy and Phytochemistry. 1(6):168-182.

35. Scalbert A. Antimicrobial properties of tannins. Phytochemistry. 1991;30(12):3875-3883.

36. Sikkema J, De Bont JAM and Poolman BM. Interaction of cyclic hydrocarbons with biological membranes. J Biol Chem. 1994;269(11):8022-8028.

37. Taiwo A Abidemi C, Oyedepo J Adebayo B, Oluwadare I and Agboto D. Nutrient content and antinutritional factor in shea butter (Butryospermum parkii) leaves. African Journal of Biotechnology. 2009;8(21):5888-5890.

38. Ugwoke CEC, Nzekwe U and Ameh GI. Phytochemical constituents and ethnobotany of the leaf extract of bitter leaf (Vernonia amygdalina) Del. Journal of Pharmaceutical and Allied Sciences. 2010;7(3):88-91.

39. Veerachari U and Bopaiah AK. Preliminary phytochemical evaluation of the leaf extract of five Cassia species. J. Chem. Pharm. Res. 2011;3(5):574-583.

40.WHO. Consolidated guidelines on the use of antiretroviral drugs for treating and preventing HIV infection. World Health Organisation June 2013 